\title{
PENERAPAN PERNYATAAN STANDAR AKUNTANSI KEUANGAN (PSAK) NOMOR 105 TENTANG PEMBIAYAAN MUDHARABAH PADA BAITUL MAAL WAT TAMWIL (STUDI EMPIRIS PADA KOPERASI SYARIAH DI ACEH BESAR)
}

\author{
Liza Adelina ${ }^{1}$, Suazhari ${ }^{* 2}$ \\ ${ }^{1,2}$ Program Studi Akuntansi Fakultas Ekonomi dan Bisnis Universitas Syiah Kuala \\ e-mail: lizaadelina96@gmail.com¹,suazhari@unsyiah.ac.id ${ }^{2}$ \\ * Corresponding Author
}

\begin{abstract}
Abstrak
This study is a descriptive study about the implementation of the Statement of Financial Accounting Standard (SFAS) 105 mudharabah financing at Sharia Cooperatives in Aceh Besar. The aim of this study was to find out how the implementation of SFAS 105 in term of recognition, measurement, presentation, and disclosure in mudharabah financing transactions at Sharia Cooveratives in Aceh Besar. The population of this study is Sharia Cooperative in Aceh Besar. Samples taken were 5 of 21 Sharia Cooperatives, which were taken using purposive sampling method. The analisys is done by comparing the implementation of accounting treatment in mudharabah financing transactions with SFAS 105. The results showed that the accounting treatment of Sharia Cooperatives in Aceh Besar in term of recognition, measurement, and disclosure was non fully in accordance with SFAS 105, while the accounting treatment on the presentation side was in accordance with SFAS 105.
\end{abstract}

Keywords: Sharia Cooperative, Mudharabah Financing, SFAS 105

\section{Pendahuluan}

BMT atau yang biasa disebut dengan koperasi syariah merupakan sebuah Lembaga Keuangan Mikro Syariah (LKMS) yang didirikan dengan menyesuaikan pada kondisi hukum dan kebutuhan pasar yang ada di Indonesia. BMT menumbuhkan dan mengembangkan bisnis usaha mikro dan kecil dengan tujuan untuk membela kepentingan dan mengangkat derajat masyarakat miskin di Indonesia (Darsono et al. 2017:113). BMT atau koperasi syariah dibangun dan dikembangkan untuk masyarakat Indonesia yang merupakan bentuk kemandirian rakyat dengan basis kearifan lokal mengoptimalkan sumber daya lokal yang ada di daerah-daerah di Indonesia. Kehadiran BMT sebagai pendatang baru dalam lembaga keuangan mikro mendapatkan respon positif dari masyarakat karena diharapkan BMT dapat menjadi suatu alternatif yang inovatif dalam jasa keuangan (Pertiwi \& Sapari, 2017). BMT sebagai lokomotif penggerak keuangan yang bagus karena bukan hanya memberikan layanan banking tetapi juga memberikan layanan sosial.

Perkembangan koperasi syariah atau BMT sangat baik di Indonesia. Meski jumlahnya masih minim tetapi menunjukkan pertumbuhan positif. Pada tahun 2016, jumlah koperasi di Indonesia sebanyak 150.223. Dari jumlah tersebut $1,5 \%$ nya adalah koperasi syariah. Modal koperasi syariah mencapai Rp. 968 milyar, modal luar Rp. 3,9 trilliun, dan volume usaha Rp. 5,2 trilliun (Humas Kemenkop dan UKM, 2016).

Pertumbuhan BMT yang baik mendorong pertumbuhan atas asetnya atau volume usahanya. Tentu dalam hal ini pihak manajemen koperasi syariah dituntut untuk lebih profesional dan semaksimal mungkin dalam mengelola keuangannya. Oleh karena itu dibutuhkan suatu pertanggungawaban manajemen atas keuangan BMT kepada pihak-pihak yang berkepentingan atau stakeholder berupa laporan keuangan. Keseragaman atas pencatatan akuntansi bagi BMT sangat diperlukan agar informasi yang disajikan mudah dipahami dan ditelusuri, akurat, relevan, andal, dan dapat dibandingkan. Oleh karena itu, diperlukan suatu standar akuntansi yang mengatur dan dapat dijadikan pedoman. Dalam hal ini IAI (Ikatan Akuntan Indonesia) berperan penting dalam menyusun standar akuntansi keuangan. 
Dalam mengatur keseragaman pencatatan transaksi akuntansi syariah, IAI untuk pertama kalinya menerbitkan PSAK 59 dan disahkan pada tanggal 1 Mei 2002 tentang akuntansi perbankan syariah, yang kemudian disusul dengan PSAK 101106 yang di sahkan pada tanggal 1 Januari 2008. Hingga saat ini, DSAKS-IAI telah mengesahkan 10 PSAK mengenai pelaporan dan produk-produk pembiayaan syariah, salah satunya adalah PSAK 105 tentang akuntansi mudharabah. PSAK 105 memuat tentang pengakuan dan pengukuran transaksi mudharabah, baik dari sisi pemilik dana (shahibul maal) maupun dari sisi pengelola dana (mudharib), prinsip pembagian hasil usaha, serta penyajian dan pengungkapan transaksi mudharabah.

Mudharabah adalah akad kerjasama antara dua belah pihak yaitu shahibul maal sebagai pemilik harta yang menyediakan dana untuk usaha dan mudharib sebagai pengelola harta atau dana dengan laba atau keuntungan akan dibagi berdasarkan kesepatakan atau nisbah yang telah disepakati antara dua pihak tersebut dan jika ada kerugian financial akan di tanggung oleh shahibul maal (Nurhayati \& Wasilah, 2015:146). Dalam lembaga keuangan syariah seperti bank syariah dan BMT, akad mudharabah bersifat fleksibel, karena dapat diterapkan pada produk perhimpunan dan penyaluran dana (Permata \& Wartoyo, 2017).

Pembiayaan mudharabah memiliki risiko yang sangat tinggi karena $100 \%$ dana berasal dari shahibul maal, oleh karenanya timbul beberapa permasalahan dalam penyaluran dana mudharabah pada koperasi syariah. Permasalahan tersebut diantaranya adalah kemungkinan adanya moral hazard dari mudharib sehingga return yang didapatkan oleh shahibul maal tidak sesuai dengan yang diharapkan, asimetri informasi antara mudharib dan shahibul maal juga menjadi permasalahannya (Purwoko \& Setiawan, 2017). Risiko yang tinggi membuat pembiayaan mudharabah masih di bawah pembiayaan musyarakah yang memiliki risiko yang lebih sedikit. Data pada tabel 1 menunjukkan bahwa pembiayaan mudharabah lebih sedikit dibandingkan dengan pembiayaan musyarakah meskipun pada tahun 2016 pembiayaan mudharabah lebih banyak dari pembiayaan musyarakah.

Tabel 1

Data pembiayaan mudharabah dan pembiayaan musyarakah tahun 2016, 2017, dan 2018 pada LKMS di Indonesia

(Dalam milyar rupiah)

\begin{tabular}{|c|c|c|c|c|c|c|}
\hline \multirow{2}{*}{ Kuartal } & \multicolumn{3}{|c|}{ Mudharabah } & \multicolumn{3}{c|}{ Musyarakah } \\
\cline { 2 - 7 } & $\mathbf{2 0 1 6}$ & $\mathbf{2 0 1 7}$ & $\mathbf{2 0 1 8}$ & $\mathbf{2 0 1 6}$ & $\mathbf{2 0 1 7}$ & $\mathbf{2 0 1 8}$ \\
\hline I & 3,80 & 3,96 & 5,31 & 2,21 & 6,21 & 7,87 \\
\hline II & 5,39 & 5,76 & 5,80 & 3,03 & 6,19 & 9,34 \\
\hline III & 5,39 & 5,81 & N/A & 3,43 & 6,65 & N/A \\
\hline$\sum$ & 14,58 & 15,53 & N/A & 8,67 & 19.05 & N/A \\
\hline
\end{tabular}

Sumber data: www.ojk.go.id

Meskipun pembiayaan mudharabah masih sedikit dibandingkan musyarakah, BMT yang berperan sebagai pengelola uang rakyat yang merupakan shahibul maal harus dapat mempertanggungjawabkan dalam bentuk laporan keuangan agar dana mudharabah yang dikelola lebih akuntabel dan transparan. Laporan keuangan harus disusun sesuai dengan standar yang telah dikeluarkan oleh IAI, dalam hal ini adalah PSAK 105.

Dalam beberapa penelitian, penulis juga menemukan ketidaksesuaian penerapan PSAK 105 atas perlakuan akuntansi pada BMT. Seperti yang disebutkan dalam penelitian Permata \& Wartoyo (2017) yaitu perlakuan akuntansi pada KJKS Muamalah Berkah Sejahtera menunjukkan bahwa kesesuaian perlakuan akuntansi pembiayaan mudharabah terletak pada sisi pengukuran dan penyajian, sedangkan pada sisi pengakuan dan pengungkapan masih belum sesuai dengan PSAK 105. Ketidaksesuaian ini terjadi karena pada saat pengakuan KJKS tidak mencatat keterlambatan pembayaran angsuran oleh nasabah sebagai piutang dan KJKS tidak mengungkapkan penyisihan kerugian investasi pembiayaan mudharabah pada laporan 
keuangannya. Pada penelitian lain, seperti penelitian Effendi (2014) pada BMT Al-Hayyu juga terdapat ketidaksesuaian perlakuan akuntansi dengan PSAK 105, karakteristik akad mudharabah pada BMT telah sesuai sedangkan pada sisi pengakuan, pengukuran, dan penyajian belum sesuai dengan PSAK 105.

Dari pemaparan di atas, dapat ditarik kesimpulan bahwa masih ada koperasi syariah yang belum menyusun laporan keuangan sesuai dengan PSAK. Oleh karena itu, penulis tertarik untuk meneliti penerapan PSAK 105 tentang pembiayaan mudharabah pada koperasi syariah sudah sesuai atau tidak. Penelitian ini dilakukan secara empiris pada koperasi-koperasi syariah di kabupaten Aceh Besar. Oleh karena itu, judul yang diajukan untuk penelitian ini adalah "Penerapan Pernyataan Standar Akuntansi Keuangan (PSAK) Nomor 105 Tentang Pembiayaan Mudharabah Pada Baitul Maal Wat Tamwil (Studi Empiris Pada Koperasi Syariah Di Aceh Besar)".

\section{Kerangka Teoritis}

\section{Akuntansi Syariah}

Secara garis besar, akuntansi syariah dapat didefinisikan secara terpisah yaitu akuntansi dan syariah. Akuntansi adalah indentifikasi suatu transaksi dengan diikuti dengan kegiatan pencatatan, penggolongan, dan pengikhtisaran sehingga menjadi laporan keuangan yang kemudian akan digunakan sebagai alat pengambilan keputusan. Sedangkan syariah dapat didefinisikan dengan segala aturanaturan berupa perintah dan larangan yang Allah turunkan kepada umat manusia untuk dipatuhi dan dijalankan agar menjaga kemaslahatan umat. Jadi, akuntansi syariah adalah suatu proses akuntansi yang dimulai dari pencatatan, penggolongan, serta pengikhtisaran atas transaksi-transaksi yang sesuai dengan aturan-aturan yang Allah SWT turunkan (Nurhayati \& Wasilah, 2015:2).

\section{Lembaga Keuangan Syariah}

Di tingkat internasional terdapat beberapa lembaga keuangan, seperti (1) Islamic Development Bank (IDB) yang mendukung riset pada bidang ekonomi, keuangan, dan perbankan Islam, lembaga ini juga mendukung penyertaan modal pada bank syariah.

(2) Accounting and Auditing Organization for Islamic Financial Institution (AAOIFI) satu lembaga internasional yang berfungsi untuk menyiapkan standar akuntansi, audit, governance, serta etika syariah bagi lembaga-lembaga keuangan islam. (3) Internasional Islamic Financial Market (IIFM) yang bertujuan untuk mengembangkan pasar modal dan pasar uang syariah secara global. (4) Islamic Financial Services Board (IFSB) merupakan lembaga yang menyusun standar bagi perbankan, pasar modal, dan asuransi syariah. (Yaya et al. 2016:16)

Di Indonesia juga terdapat lembaga keuangan seperti bank umum syariah, bank pembiayaan rakyat syariah, unit usaha syariah bank konvensional, Baitul Maal wat Tamwil (BMT), asuransi syariah, pasar modal syariah, reksa dana syariah, ar-rahnu dan Lembaga Amil Zakat (LAZ) serta Badan Amil Zakat (BAZ). BMT merupakan salah satu lembaga microfinance yang dicetuskan dan didirikan di Indonesia yang kemudian diterapkan diberbagai negara muslim lainnya seperti Malaysia (Yaya et al. 2016:20).

\section{Baitul Maal wat Tamwil (BMT)}

BMT adalah Lembaga Keuangan Mikro Syariah (LKMS) yang berbasis koperasi pada awalnya didirikan dan dikembangkan dengan menyesuaikan kondisi hukum dan kebutuhan pasar di Indonesia. BMT menumbuhkan dan mengembangkan bisnis usaha mikro daan kecil dengan tujuan untuk membela kepentingan serta mengangkat martabat dan derajat fakir miskin (Darsono et al. 2017:113).

Menurut Yaya et al. (2016:20) Baitul Maal wat Tamwil (BMT) mempunyai dua istilah yaitu Baitul maal dan Baitul tamwil, kedua istilah tersebut akan diuraikan sebagai berikut:

a. Baitul maal (rumah harta) adalah suatu istilah yang digunakan untuk organisasi yang yang mempunyai peran dalam mengumpulkan dan menyalurkan dana non-profit, seperti zakat, infak, dan sedekah (ZIS).

b. Baitul tamwil (rumah pengembangan harta) adalah suatu istilah untuk organisasi yang mempunyai fungsi ganda yaitu fungsi sosial dan fungsi komersial yang bertugas untuk mengumpulkan dan menyalurkan dana komersial.

\section{Pembiayaan Mudharabah}

Nurhayati \& Wasilah, (2015:146) mendefinisikan mudharabah dengan suatu akad 
kerjasama diantara dua belah pihak yaitu shahibul maal sebagai pemilik harta yang menyediakan dana untuk usaha dan mudharib sebagai pengelola harta atau dana dengan laba atau keuntungan akan dibagi berdasarkan kesepakatan atau nisbah bagi hasil yang disepakati antara dua pihak tersebut dan jika ada kerugian financial akan di tanggung oleh shahibul maal. Mudharabah dibagi menjadi tiga jenis, yaitu:

a. Mudharabah mutlaqah, adalah suatu akad mudharabah dimana pemilik dana memberikan kebebasan kepada pengelola dana dalam mengelola investasinya.

b. Mudharabah muqayyadah, adalah suatu akad mudharabah dimana pemilik dana memberikan batasan kepada pengelola dana, batasan tersebut antara lain mengenai tempat, cara, dan objek investasinya.

c. Mudharabah musytarakah, adalah akad mudharabah dimana pengelola dana menyertakan modal dalam kerjasama investasi.

\section{Pernyataan Standar Akuntansi Keuangan (PSAK) 105}

\section{Prinsip Pembagian Hasil Usaha}

PSAK 105 menyatakan bahwa "pembagian hasil usaha dapat dilakukan dengan 2 cara, yaitu dengan bagi hasil dan bagi laba. Dasar pembagian untuk bagi hasil adalah laba bruto sedangkan dasar pembagian untuk bagi laba adalah laba bersih".

\section{Pengakuan dan Pengukuran untuk Pemilik Dana}

Pengakuan dan pengukuran untuk pemilik dana diatur dalam PSAK 105 dari paragraf 12-19 yang menyatakan bahwa Dana mudharabah yang disalurkan oleh pemilik dana diakui sebagai investasi mudharabah pada saat pembayaran kas atau penyerahan aset nonkas kepada pengelola dana.

Pengukuran untuk investasi mudharabah adalah sebagai berikut:

a. Investasi mudharabah dalam bentuk kas diukur sebesar kas yang dibayarkan;

b. Investasi mudharabah dalam bentuk aset nonkas diukur sebesar nilai wajar aset nonkas pada saat penyerahan:

i. Jika nilai wajar lebih tinggi dari pada nilai tercatatnya diakui, maka selisihnya diakui sebagai keuntungan tangguhan dan diamortisasi sesuai jangka waktu akad mudharabah.

ii. jika nilai wajar lebih rendah daripada nilai tercatatnya, maka selisihnya diakui sebagai kerugian.

Jika nilai investasi mudharabah turun sebelum memulai usaha yang disebabkan karena rusak, hilang atau faktor lain yang bukan suatu kelalaian atau kesalahan pihak pengelola dana, maka penurunan nilai tersebut diakui sebagai kerugian dan mengurangi saldo investasi mudharabah.

Jika sebagian investasi mudharabah hilang setelah dimulainya usaha tanpa adanya kelalaian atau kesalahan pengelola maka kerugian tersebut diperhitungkan pada saat bagi hasil. Usaha mudharabah dianggap mulai berjalan sejak dana atau modal usaha mudharabah diterima olek pihak pengelola dana.

Dalam investasi mudharabah yang diberikan dalam aset nonkas dan aset nonkas tersebut mengalami penurunan nilai pada saat atau setelah barang dipergunakan secara efektif dalam kegiatan usaha mudharabah, maka kerugian tersebut tidak langsung mengurangi jumlah investasi, namun diperhitungkan pada saat pembagian bagi hasil.

Kelalaian atas kesalahan pengelola dana, antara lain ditunjukkan oleh:

a. Persyaratan yang ditentukan dalam akad tidak dipenuhi

b. Tidak terdapat kondisi diluar kemampuan (force majeur) yang lazim atau yang telah ditentukan dalam akad

c. Hasil keputusan dari intitusi yang berwenang.

Jika akad mudharabah berakhir sebelum atau saat akad jatuh tempo dan belum dibayar oleh pengelola dana, maka investasi mudharabah diakui sebagai piutang.

\section{Pengakuan dan Pengukuran untuk Penghasilan Usaha}

Pengakuan dan pengukuran untuk penghasilan usaha diatur dalam PSAK 105 dari paragraf 20 sampai 24, yaitu: Jika investasi mudharabah melebihi satu periode pelaporan, penghasilan usaha diakui dalam periode terjadinya hak bagi hasil sesuai dengan nisbah yang disepakati. Kerugian yang terjadi dalam satu periode sebelum akad mudharabah berakhir diakui sebagai kerugian dan bentuk penyisihan kerugian 
investasi. Pada saat akad mudharabah berakhir, selisih antara:

a. Investasi mudharabah dikurangi penyisihan kerugian investasi, dan

b. Pengembalian investasi mudharabah diakui sebagai keuntungan atau kerugian.

Pengakuan penghasilan usaha mudharabah dalam praktik dapat diketahui berdasarkan laporan bagi hasil atas realisasi penghasilan usaha dari pengelola dana. Tidak diperkenankan mengakui pendapatan dari proyeksi hasil usaha. Kerugian akibat kelalaian atau kesalahan dari pengelola dana dibebankan atas pengelola dana dan tidak mengurangi investasi mudharabah. Bagian hasil usaha yang belum dibayarkan oleh pengelola dana diakui sebagai piutang.

\section{Pengakuan dan Pengukuran untuk Pengelola Dana}

Pengakuan dan pengukuran untuk pengelola dana diatur dalam PSAK 105 pada paragraf 25 sampai dengan paragraf 30 , yang menyatakan bahwa Dana yang diterima dari pemilik dana dalam akad mudharabah diakui sebagai dana syirkah temporer sebesar jumlah kas atau sebesar nilai wajar jika investasi tersebuat dalam bentuk investasi aset nonkas yang diterima. Pada akhir periode, nilai syirkah temporer dicatat sebesar nilai yang tercatat. Jika pengelola dana menyalurkan dana syirkah temporer yang diterima maka pengelola dana mengakui sebagai aset sesuai ketentuan pada paragraf 12-13 .

Pengelola dana mengakui pendapatan atau penyaluran dana syirkah temporer secara bruto sebelum dikurangi dengan bagian hak pemilik dana. Bagi hasil mudharabah dapat dilakukan dengan menggunakan dua prinsip, yaitu bagi hasl atau bagi laba seperti yang dijelaskan pada paragraf 11. Hak pihak ketiga atas bagi hasil dana syirkah temporer yang sudah diperhitungkan tetapi belum dibagikan kepada pemilik dana diakui sebagai liabilitas atau utang sebesar bagi hasil yang menjadi bagian hak pemilik dana. Kerugian yang diakibatkan oleh kesalahan atau kelalaian pengelola dana diakui sebagai beban pengelola dana.

Pengakuan dan pengukuran untuk akuntansi pengelola dana pada mudharabah musytarakah diatur dalam PSAK 105 paragraf 31-35 yang menyatakan bahwa: Jika pengelola dana juga menyertakan dana dalam usaha mudharabah maka penyaluran dana milik pengelola dana tersebut diakui sebagai investasi mudharabah. Akad mudharabah musytarakah adalah perpaduan antara akad mudharabah dan akad musyarakah. Dalam mudharabah musytarakah, pengelola dana (berdasarkan akad mudharabah) menyertakan juga dananya dalam investasi bersama (berdasarkan akad musyarakah). Pemilik dana musyarakah (musytarik) memperoleh bagian hasil usaha sesuai porsi dana yang disetorkan. Pembagian hasil usaha antara pengelola dana dan pemilik dana adalah sebesar hasil usaha musyrakah setelah dikurangi porsi pemilik dana sebagai pemilik dana musyarakah.

Pembagian hasil investasi mudharabah musytarakah dapat dilakukan sebagai berikut:

a. Hasil investasi dibagi antara pengelola dana (mudharib) dan pemilik dana (shahibul maal) sesuai dengan nisbah yang disepakati, selanjutnya bagian hasil investasi setelah dikurangi untuk pengelola dana tersebut dibagi antara pengelola dana (sebagai musytarik) dengan pemilik dana sesuai dengan porsi modal masing-masing.

b. Hasil investasi dibagi antara pengelola dana (sebagai musytarik) dan pemilik dana sesuai dengan porsi modal masing-masing, selanjutnya bagian hasil investasi setelah dikurangi untuk pemilik dana (sebagai musytarik) tersebut dibagi antara pengelola dana (sebagai mudharib) dengan pemilik dana sesuai dengan nisbah yang disepakati.

Jika kerugian atas investasi, maka kerugian dibagi sesuai dengan porsi modal para musytarik.

\section{Penyajian}

Penyajian atas laporan akad mudharabah diatur dalam PSAK 105 paragraf 36 dan 37 yang menyatakan bahwa pemilik dana menyajikan investasi mudharabah dalam laporan keuangan sebesar nilai tercatat. Pengelola dana menyajikan transaksi mudharabah dalam laporan keuangan, dengan:

(a) Dana syirkah temporer dari pemilik dana disajikan sebesar nilai tercatatnya untuk setiap jenis mudharabah, dan

(b) Bagi hasil dana syirkah temporer yang udah diperhitungkan tetapi belum diserahkan kepada pemilik dana disajikan sebagai pos bagi hasil yang belum dibagikan di liabilitas. 


\section{Pengungkapan}

Pemilik dana mengungkapkan hal-hal terkait transaksi mudharabah, tetapi tidak terbatas pada:

a. Isi kesepakatan utama usaha mudharabah, seperti porsi dana, pembagian hasil usaha, aktivitas usaha mudharabah, dan lain-lain.

b. Rincian jumlah investasi mudharabah berdasarkan jenisnya

c. Penyisihan kerugian investasi mudharabah selama periode berjalan

d. Pengungkapan yang diperlukan sesuai PSAK 101: penyajian pelaporan keuangan syariah.

Pengelola dana mengungkapkan hal-hal terkait transaksi mudharabah, tetapi tidak terbatas pada:

a. Isi kesepakatan utama usaha mudharabah, seperti porsi dana, pembagian hasil usaha, aktivitas usaha mudharabah, dan lain-lain

b. Rincian dana syirkah temporer yang diterima berdasarkan jenisnya

c. Penyaluran dana yang berasal dari mudharabah muqayyadah

d. Pengungkapan yang diperlukan sesuai PSAK 101: penyajian pelaporan keuangan syariah.

\section{Penelitian Terdahulu}

Ikhsan \& Haridhi (2017) dalam penelitiannya yang berjudul penerapan standar akuntansi keuangan syariah pada koperasi jasa keuangan syariah yang melakukan penelitiannya pada Baitul Qiradh di Kota Banda Aceh menyatakan bahwa BQ di Kota Banda Aceh belum mampu menyusun dan menyajikan laporan keuangan syariah sesuai dengan PSAK 101 tentang penyajian laporan keuangan syariah secara menyeluruh. Namun pada transaksi mudharabah yang disalurkan oleh BQ Surya Madinah sisi pengakuan, pengukuran, penyajian, dan pengungkapan yang dilakukan sudah sesuai dengan PSAK 105 tentang akuntansi mudharabah.

Irlanda \& Djazari (2017) dalam penelitian yang berjudul Analisis Penerapan PSAK No. 105 atas Pembiayaan Mudharabah Pada BPRS Bangun Drajat Warga dan BPRS Madina Mandiri Sejahtera menunjukkan bahwa perlakuan akuntansi pada kedua BPRS tersebut pada sisi pengakuan belum sesuai, ketidaksesuaian terjadi karena BPRS tidak melakukan pencatatan pada angsuran yang telambat dibayar oleh nasabah. BPRS masih menggunakan pencatatan dengan metode cash basis sehingga keterlambatan angsuran tidak diakui karena pembayaran dicatat ketika kas masuk. Sedangkan pada sisi pengukuran, penyajian, dan pengungkapan telah sesuai dengan PSAK 105.

Penelitian Permata \& Wartoyo (2017) dengan judul analisis penerapan PSAK no. 105 pada tabungan berjangka mudharabah dan pembiayaan mudharabah menyatakan bahwa perlakuan akuntansi baik di sisi pengakuan, pengukuran, penyajian maupun pengungkapan pada tabungan berjangka di BMT Gunungjati Cabang Kedawung Cirebon sudah sesuai dengan PSAK No. 105. Akan tetapi perlakuan akuntansi terhadap produk pembiayaan mudharabah tidak sepenuhnya sesuai dengan PSAK 105. Ketidaksesuaian tersebut terdapat pada sisi pengakuan dan pengungkapan yaitu pada saat pengakuan piutang, keuntungan, dan kerugian serta tidak adanya pengungkapan penyisihan kerugian investasi mudharabah pada laporan keuangannya.

Pertiwi \& Sapari (2017) dalam penelitiannya yang berjudul penerapan sistem bagi hasil dan perlakuan akuntansi pembiayaan mudharabah menyatakan bahwa KJKS Muamalah Berkah Sejahtera telah menjalankan prosedur pembiayaan mudharabah, proses pemberian informasi tentang persyaratan pembiayaan mudharabah dengan baik, begitu pula dengan rukun dan syarat pembiayaan mudharabah telah terpenuhi, pembiayaan mudharabah telah dilakukan dengan sistem syariah. perlakuan akuntansi dan perhitungan bagi hasil sesuai dengan PSAK No. 105.

Penelitian Effendi (2014) yang berjudul implementasi akuntansi syariah pada pembiayaan mudharabah berdasarkan PSAK no. 105 pada KJKS BMT Al-Hayyu kota Batam mengemukakan hasil yang adalah bahwa perlakuan akuntansi pada akad mudharabah di BMT Al-Hayyu belum diimplementasikan secara menyeluruh, untuk karakteristik akad mudharabah sudah sesuai tetapi pada sisi pengakuan, pengukuran, dan penyajian masih belum menerapkan PSAK no. 105. 


\section{Kerangka Pemikiran}

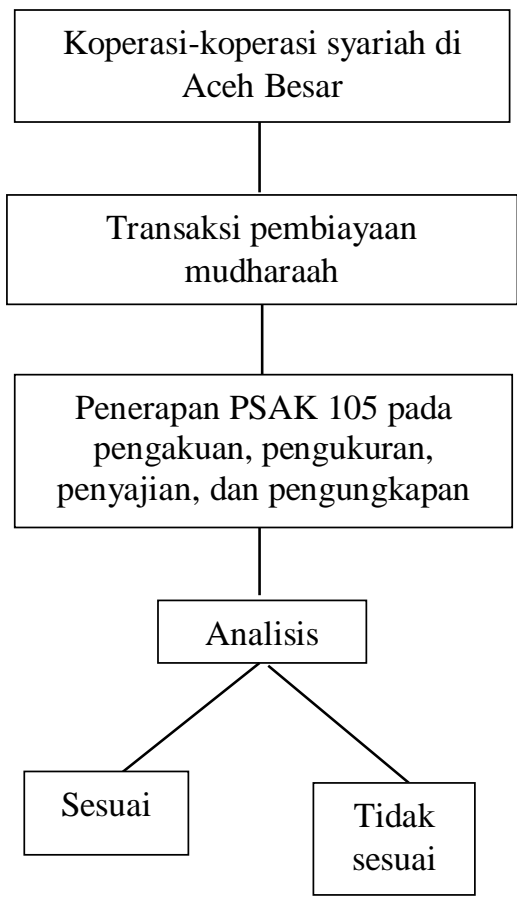

\section{Gambar 1 Kerangka Pemikiran}

\section{Metode Penelitian}

\section{Desain Penelitian}

Menurut Sekaran \& Bougie (2013:95), desain penelitian adalah suatu perencanaan untuk pengumpulan, pengukuran, dan analisis data, berdasarkan pertanyaan penelitian penelitian. Desain penelitian terdiri atas enam aspek, yaitu tujuan penelitian, jenis penelitian, tingkat intervensi peneliti, situasi penelitian, unit analisis, dan horizon waktu penelitian.

Tujuan penelitian adalah penelitian deskriptif untuk menjelaskan apakah koperasi-koperasi syariah di Aceh Besar telah menerapkan PSAK no. 105 tentang pembiayaan mudharabah dan apakah pengakuan, pengukuran, dan penyajian pada koperasikoperasi syariah tersebut telah sesuai dengan PSAK no. 105. Jenis penelitian yang digunakan adalah penelitian kualitatif dengan pendekatan deskriptif. Dalam penelitian ini peneliti menggunakan tingkat intervensi minimal. Dalam penelitian ini peneliti menggunakan tingkat intervensi minimal. Sekaran \& Bougie (2013:99), menjelaskan bahwa dalam tingkat intervensi minimal, peneliti hanya mengumpulkan data dan tidak ikut mempengaruhi variabel sehingga akan mempengaruhi hasil penelitian.
Penelitian ini menggunakan situasi alami atau situasi normal. Horizon waktu yang digunakan dalam penelitian ini adalah one shot atau cross-sectional. Menurut Sekaran \& Bougie (2013:106), penelitian cross-sectional adalah sebuah penelitian dimana data yang dikumpulkan hanya sekali, atau beberapa hari, beberapa minggu, beberapa bulan untuk menjawab pertanyaan penelitian. Unit analisis adalah tingkat kesatuan data yang dikumpulkan dalam tahap analisis data. Dalam hal ini peneliti mengambil unit analisis yaitu unit organisasi atau koperasi syariah di Aceh Besar.

\section{Populasi dan Sampel Penelitian}

Menurut Sekaran \& Bougie (2013:240-241), populasi merupakan keseluruhan kelompok, instansi, organisasi, orang, kejadian atau hal lain yang ingin di investigasikan. Sedangkan sampel adalah bagian dari populasi berupa anggota, kelompok, atau bagian kejadian yang ada dalam populasi. Populasi yang diambil dalam penelitian ini adalah seluruh koperasi syariah di Aceh Besar yang tercatat pada Dinas Koperasi dan UMKM Kabupaten Aceh Besar, yaitu sebanyak 21 koperasi syariah. Sampel yang diambil hanya sebanyak 5 koperasi syariah, yang diambil menggunakan metode purposive sampling, yaitu teknik penentuan sampel berdasarkan pertimbangan yang sesuai dengan tujuan dan masalah penelitian. Adapun kriterianya adalah:

a. Koperasi syariah yang terdaftar pada Dinas Koperasi dan UMKM Aceh Besar.

b. Koperasi syariah yang masih beroperasi.

c. Koperasi syariah yang mempunyai produk pembiayaan mudharabah.

Adapun koperasi yang diambil adalah sebagai berikut.

1. Koperasi Syariah Baitul Qiradh Al-Istiqamah.

2. Koperasi Syariah Baitul Qiradh Karya Insan Sejahtera 43.

3. Koperasi Syariah Baitul Qiradh Abu Indrapuri.

4. Koperasi Syariah Mitra Niaga.

5. Koperasi Simpan Pinjam Dana Mandiri Syariah.

\section{Sumber dan Teknik Pengumpulan Data}

Sumber data yang digunakan adalah data primer. Data primer merupakan data yang didapatkan secara langsung melalui observasi, wawancara, dan 
kuesioner. Informasi mengenai penyajian laporan keuangan dan transaksi pembiayaan mudharabah di dapat melalui pengisian kuesioner dan wawancara dengan bagian keuangan yang berhubungan langsung dengan laporan keuangan koperasi syariah. Teknik pengumpulan sampel yang digunakan oleh penulis dalam penelitian ini adalah:

1. Studi kepustakaan

Sebelum melakukan observasi secara langsung ke lapangan, peneliti terlebih dahulu mengumpulkan data dari buku-buku ataupun literatur-literatur yang sesuai dengan masalah yang diteliti untuk mendapatkan teori kemudian akan dijadikan pedoman untuk melakukan analisis terhadap data yang didapat di lapangan.

2. Studi lapangan

a. Observasi, adalah mengamati secara langsung keadaan instansi yang akan dijadikan objek penelitian. Observasi dilakukan dengan melakukan pengamatan secara langsung pada masing-masing koperasi syariah yang ada di Aceh Besar.

b. Kuesioner, adalah serangkaian pertanyaan yang sudah diformulasikan sebelumnya dimana responden dapat mengisi jawaban mereka, biasanya dalam alternatif definisi yang jelas (Sekaran \& Bougie, 2013:147). Kuisioner akan dibagikan kepada bagian keuangan yang bertanggungjawab terhadap laporan keuangan pada masing-masing koperasi syariah. Setelah semua isian kuesioner telah terkumpul, maka langkah selanjutnya adalah menghitung skor (nilai) pada setiap indikator yang bertujuan untuk mengetahui persentase penerapan PSAK 105 pada koperasi syariah. Dalam menetapkan nilainya, penulis menggunakan formulasi dari Sugiyono (2013), dengan nilai 1 untuk jawaban Ya dan 0 untuk jawaban Tidak. Dengan formulasi sebagai berikut:

$$
P R=\frac{S C}{S I} x 100 \%
$$

Dimana:

PR $=$ Presentase Capaian

SC $\quad=$ Jumlah Skor Capaian

$$
\begin{array}{ll}
\mathrm{SI} & =\text { Jumlah Skor Ideal } \\
100 \% & =\text { Jumlah Tetap }
\end{array}
$$

c. Wawancara, adalah melakukan tanya jawab atau dialog dengan pihak yang berkaitan dalam menyusun laporan keuangan instansi atau koperasi syariah tersebut. Dalam penelitian ini penulis menggunakan teknik wawancara terstruktur. Wawancara terstruktur adalah wawancara dimana peneliti memiliki pedoman yang sistematis atas pertanyaan yang diajukan.

d. Dokumentasi, adalah mengumpulkan data pendukung yang digunakan dalam penelitian. Tujuan dokumentasi adalah untuk melengkapi data yang didapatkan dari hasil observasi, kuisioner, dan wawancara. Data yang diperlukan dalam penelitian ini berupa laporan keuangan, catatan atau dokumen-dokumen, brosur, formulir pembiayaan, dan akad yang menyangkut pembiayaan mudharabah pada koperasi syariah di Aceh Besar.

\section{Instrumen Penelitian}

Instrumen penelitian adalah suatu alat yang digunakan untuk mengukur suatu fenomena, baik fenomena alam maupun fenomena sosial yang diamati, fenomena ini secara spesifik disebut variabel penelitian (Sugiyono, 2013:146). Instrumen yang digunakan dalam penelitian ini adalah kuesioner, wawancara, dan dokumentasi. Instrumen dalam penelitian ini disusun berdasarkan pengakuan, pengukuran, penyajian, dan pengungkapan. Kisi-kisi panduan kuesioner dapat dilihat pada tabel 2 .

\section{Teknik Analisis Data}

Teknik analisis data adalah proses pengorganisasian dan pengaturan secara sistematik data ke dalam suatu pola, kategori, dan satuan uraian dasar sehingga dapat di temukan tema dan hipotesis yang disarankan dan untuk meningkatkan pemahaman terhadap bahan-bahan tersebut untuk dipresentasikan kepada orang lain (Moleong, 2012). Adapun teknik analisis data atau metode analisis data yang digunakan dalam penelitian ini adalah metode analisis kualitatif 
deskiptif. Langkah-langkah teknik analisis data yang digunakan dalam penelitian ini adalah:

a. Mengumpulkan data berupa hasil wawancara, hasil kuesioner, laporan keuangan, brosur serta data lainnya yang telah didapatkan dari lapangan. Data tersebut, kemudian diklasifikasikan dan diseleksi untuk memastikan data yang didapat tersebut benar-benar relevan.

b. Mengkaji kembali data-data mudharabah yang telah diseleksi tersebut.

c. Menyajikan data berupa teori-teori yang berkaitan dengan PSAK 105 sehingga memudahkan dalam menganalisa data.

d. Menganalisa data dengan membandingkan dan menyesuaikan PSAK 105 dengan konsep, pelaksanaan, dan penerapan PSAK 105 pada transaksi mudharabah. Pada data kuesioner, analisa data dilakukan dengan menghitung skor capaian, hasil persentase untuk mengetahui seberapa besar tingkat penerapan PSAK 105 pada koperasi syariah tersebut.

e. Melakukan penafsiran dan pengulasan kembali dengan deskriptif verifikasi.

f. Penarikan kesimpulan dan memberikan saransaran terhadap hasil analisis. Penarikan kesimpulan merupakan proses akhir kegiatan analisis dalam data kualitatif.

Tabel 2

Kisi-kisi Panduan Kuesioner

\begin{tabular}{|c|c|c|c|}
\hline Standar & Sub Variabel & Indikator & No. Item \\
\hline \multirow[t]{4}{*}{$\begin{array}{l}\text { PSAK } 105 \\
\text { Tentang } \\
\text { akuntansi } \\
\text { mudharabah }\end{array}$} & Pengakuan & $\begin{array}{l}\text { - Kas yang disalurkan diakui sebagai investasi mudharabah } \\
\text { - Aset nonkas yang diserahkan diakui sebagai investasi } \\
\text { mudharabah } \\
\text { - Nilai investasi turun sebelum dimulai usaha diakui sebagai } \\
\text { kerugian } \\
\text { - Investasi mudharabah diakui sebagai piutang apabila belum } \\
\text { dibayarkan oleh pengelola dana pada saat akad berakhir } \\
\text { - Penghasilan usaha diakui sesuai dengan nisbah bagi hasil yang } \\
\text { disepakati } \\
\text { - Kerugian yang terjadi dalam periode akad diakui sebagai } \\
\text { kerugian } \\
\text { - Hasil usaha yang belum dibayarkan pengelola dana diakui } \\
\text { sebagai piutang }\end{array}$ & $1 \mathrm{~s} / \mathrm{d} 7$ \\
\hline & Pengukuran & $\begin{array}{l}\text { - Investasi mudharabah dalam bentuk kas diukur sejumlah kas } \\
\text { - yang dibayarkan } \\
\text { - Investasi mudharabah dalam bentuk aset nonkas diukur sebesar } \\
\text { nilai wajar } \\
\text { - Sebagian investasi hilang setelah dimulai usaha bukan karena } \\
\text { kelalaian, kerugian diperhitungkan pada saat bagi hasil } \\
\text { - Kerugian akibat kelalaian pengelola dana dibebankan pada } \\
\text { pengelola dana dan tidak mengurangi investasi mudharabah }\end{array}$ & $8 \mathrm{~s} / \mathrm{d} 11$ \\
\hline & Penyajian & $\begin{array}{l}\text { - Menyajikan investasi mudharabah dalam laporan keuangan } \\
\text { sebesar nilai tercatat }\end{array}$ & 12 \\
\hline & Pengungkapan & $\begin{array}{l}\text { - Mengungkapkan isi kesepakatan utama } \\
\text { - Mengungkapkan rincian jumlah investasi mudharabah } \\
\text { - Mengungkapkan penyisihan kerugian investasi } \\
\text { - Pengungkapan yang diperlukan sesuai PSAK } 101\end{array}$ & $13 \mathrm{~s} / \mathrm{d} 18$ \\
\hline
\end{tabular}

Sumber: Data diolah 2018

\section{Hasil dan Pembahasan}

Pengakuan
Perlakuan akuntansi atas pengakuan pada Koperasi Syariah Baitul Qiradh Al-Istiqamah, Koperasi Syariah Baitul Qiradh Karya Insan Sejahtera 
43, dan Koperasi Syariah Baitul Qiradh Abu Indrapuri telah sesuai dengan PSAK 105, sedangkan Koperasi Syariah Mitra Niaga dan Koperasi Simpan Pinjam
Dana Mandiri Syariah belum sepenuhnya sesuai. Hal tersebut dapat dilihat pada tabel 3.

Tabel 3

Tingkat Persentase Kesesuaian Penerapan PSAK 105 atas Pengakuan

\begin{tabular}{|l|l|c|c|}
\hline No. & \multicolumn{1}{|c|}{ Koperasi Syariah } & Perhitungan Skor Capaian & Hasil \\
\hline 1. & Kopsyah BQ Al-Istiqamah & $\frac{7}{7} \times 100 \%$ & $100 \%$ \\
\hline 2. & Kopsyah BQ Karya Insan Sejahtera 43 & $\frac{7}{7} \times 100 \%$ & $100 \%$ \\
\hline 3. & Kopsyah Mitra Niaga & $\frac{6}{7} \times 100 \%$ & $86 \%$ \\
\hline 4. & KSP Dana Mandiri Syariah & $\frac{4}{7} \times 100 \%$ & $57 \%$ \\
\hline 5. & Kopsyah BQ Abu Indrapuri & $\frac{7}{7} \times 100 \%$ & $100 \%$ \\
\hline
\end{tabular}

Sumber: Data Diolah 2018

Ketidaksesuaian yang terjadi pada Kopsyah Mitra Niaga dikarenakan bagi hasil pembiayaan mudharabah masih menggunakan margin seperti halnya pada akad murabahah dengan marginnya adalah 20\% pertahun. Sedangkan pada KSP Dana Mandiri Syariah, ketidaksesuaian itu yaitu mereka tidak mengakui aset nonkas sebagai pembiayaan dikarenakan KSP Dana Mandiri Syariah tidak melayani pembiayaan mudharabah berupa aset nonkas. Pembiayaan atas aset nonkas dilakukan dengan akad murabahah. Begitu pula pengakuan pada kerugian mudharabah sebelum terjadinya usaha yaitu KSP Dana Mandiri Syariah tidak menanggung kerugian pembiayaan mudharabah yang disebabkan hilang atau faktor lainnya sebelum dimulainya usaha apabila kesalahan tersebut bukan kelalaian atau kesalahan nasabah dan diakui sebagai kerugian. Mereka memberikan pembiayaan kepada nasabah yang sudah mempunyai usaha dan mereka belum menemukan kasus hilangnya dana pembiayaan. KSP Dana Mandiri Syariah juga tidak mengakui nisbah bagi hasil sesuai dengan nisbah yang disepakati, yaitu Bagi hasil pembiayaan mudharabah masih menggunakan margin seperti halnya pada akad murabahah. Marginnya adalah $20 \%$ pertahun untuk pembiayaan diatas Rp. 10.000.000,- dan $22 \%$ pertahun untuk pembiayaan dibawah Rp. 10.000.000,-.

\subsection{Pengukuran}

Perlakuan akuntansi atas pengukuran pada Koperasi Syariah Baitul Qiradh Al-Istiqamah dan Koperasi Syariah Baitul Qiradh Karya Insan Sejahtera 43 telah sesuai, sedangkan pada Koperasi Syariah Mitra Niaga, Koperasi Simpan Pinjam Dana Mandiri Syariah, dan Koperasi Syariah Baitul Qiradh Abu Indrapuri belum sepenuhnya sesuai. Hal tersebut dapat dilihat pada tabel berikut.

Tabel 4

Tingkat Persentase Kesesuaian Penerapan PSAK 105 atas Pengukuran

\begin{tabular}{|l|l|c|l|}
\hline No. & Koperasi Syariah & Perhitungan Skor Capaian & Hasil \\
\hline 1. & Kopsyah BQ Al-Istiqamah & $\frac{4}{4} \times 100 \%$ & $100 \%$ \\
\hline 2. & Kopsyah BQ Karya Insan Sejahtera 43 & $\frac{4}{4} \times 100 \%$ & $100 \%$ \\
\hline 3. & Kopsyah Mitra Niaga & $\frac{3}{4} \times 100 \%$ & $75 \%$ \\
\hline 4. & KSP Dana Mandiri Syariah & $\frac{3}{4} \times 100 \%$ & $75 \%$ \\
\hline 5. & Kopsyah BQ Abu Indrapuri & $\frac{3}{4} \times 100 \%$ & $75 \%$ \\
\hline
\end{tabular}

Sumber: Data Diolah 2018 
Ketidaksesuaian yang terjadi pada Kopsyah Mitra Niaga dikarenakan jika aset mudharabah hilang atau rusak bukan karena adanya kelalaian dari pihak nasabah maka kerugian tersebut tidak sepenuhnya menjadi tanggung jawab Kopsyah Mitra Niaga dan tidak diperhitungkan pada saat pembagian hasil. Hal ini karena Kopsyah Mitra Niaga lebih banyak memberikan pembiayaan kepada nasabah yang telah mempunyai usaha.

$$
\text { Pada KSP Dana Mandiri Syariah, }
$$
ketidaksesuaian terjadi Jika aset mudharabah hilang atau rusak bukan karena adanya kelalaian dari pihak nasabah maka kerugian tersebut tidak sepenuhnya menjadi tanggung jawab KSP Dana Mandiri Syariah dan tidak diperhitungkan pada saat pembagian hasil. Hal ini karena KSP Dana Mandiri Syariah lebih

banyak memberikan pembiayaan kepada nasabah yang telah mempunyai usaha.

Pada Kopsyah BQ Abu Indrapuri ketidaksesuaian terjadi jika aset mudharabah hilang atau rusak bukan karena adanya kelalaian dari pihak nasabah maka kerugian tersebut tidak sepenuhnya ditanggung oleh pihak Kopsyah BQ Abu Indrapuri.

\section{Penyajian}

Perlakuan akuntansi atas penyajian pada Koperasi Syariah Baitul Qiradh Al-Istiqamah, Koperasi Syariah Baitul Qiradh Karya Insan Sejahtera 43, Koperasi Syariah Mitra Niaga dan Koperasi Simpan Pinjam Dana Mandiri Syariah telah sesuai dengan PSAK 105. Hal tersebut dapat dilihat pada tabel 5.

\section{Tabel 5}

Tingkat Persentase Kesesuaian Penerapan PSAK 105 atas Penyajian

\begin{tabular}{|l|l|c|c|}
\hline No. & \multicolumn{1}{|c|}{ Koperasi Syariah } & Perhitungan Skor Capaian & Hasil \\
\hline 1. & Kopsyah BQ Al-Istiqamah & $\frac{1}{1} \times 100 \%$ & $100 \%$ \\
\hline 2. & Kopsyah BQ Karya Insan Sejahtera 43 & $\frac{1}{1} \times 100 \%$ & $100 \%$ \\
\hline 3. & Kopsyah Mitra Niaga & $\frac{1}{1} \times 100 \%$ & $100 \%$ \\
\hline 4. & KSP Dana Mandiri Syariah & $\frac{1}{1} \times 100 \%$ & $100 \%$ \\
\hline 5. & Kopsyah BQ Abu Indrapuri & $\frac{1}{1} \times 100 \%$ & $100 \%$ \\
\hline
\end{tabular}

Sumber: Data Diolah 2018

Kopsyah BQ Al-Istiqamah, Kopsyah BQ Karya Insan Sejahtera 43, Kopsyah Mitra Niaga, KSP Dana Mandiri Syariah, dan Kopsyah BQ Abu Indrapuri menyajikan pembiayaan mudharabah pada akun pembiayaan pada sisi aktiva lancar di laporan keuangan neraca.

\subsection{Pengungkapan}

Penerapan PSAK 105 atas pengungkapan pada Kopsyah BQ Al-Istiqamah, Kopsyah BQ Karya Insan Sejahtera 43, Kopsyah Mitra Niaga, KSP Dana Mandiri Syariah, dan Kopsyah BQ Abu Indrapuri secara keseluruhan belum sesuai, hal tersebut dapat dilihat pada tabel 6 .

Tabel 4.6

Tingkat Persentase Kesesuaian Penerapan PSAK 105 atas Pengungkapan

\begin{tabular}{|l|l|c|c|}
\hline No. & \multicolumn{1}{|c|}{ Koperasi Syariah } & Perhitungan Skor Capaian & Hasil \\
\hline 1. & Kopsyah BQ Al-Istiqamah & $\frac{3}{4} \times 100 \%$ & $75 \%$ \\
\hline 2. & Kopsyah BQ Karya Insan Sejahtera 43 & $\frac{3}{4} \times 100 \%$ & $75 \%$ \\
\hline 3. & Kopsyah Mitra Niaga & $\frac{3}{4} \times 100 \%$ & $75 \%$ \\
\hline 4. & KSP Dana Mandiri Syariah & $\frac{3}{4} \times 100 \%$ & $75 \%$ \\
\hline 5. & Kopsyah BQ Abu Indrapuri & $\frac{3}{4} \times 100 \%$ & $75 \%$ \\
\hline
\end{tabular}

Sumber: Data Diolah 2018 
Ketidaksesuaian terdapat pada Kopsyah BQ AlIstiqamah, Kopsyah BQ Karya Insan Sejahtera 43, Kopsyah Mitra Niaga, KSP Dana Mandiri Syariah, dan Kopsyah BQ Abu Indrapuri yaitu: tidak sepenuhnya mengungkapkan hal-hal yang diperlukan sesuai dalam PSAK 101 tentang penyajian pelaporan keuangan syariah, seperti dasar pengukuran akuntansi untuk pembiayaan mudharabah.

\section{Kesimpulan, keterbatasan, dan Saran Kesimpulan}

Berdasarkan hasil analisis pada 5 koperasi syariah di Aceh Besar yang diuraikan pada bab sebelumnya, dapat ditarik kesimpulan adalah sebagai berikut.

1. Perlakuan akuntansi atas pengakuan pada Koperasi Syariah Baitul Qiradh Al-Istiqamah, Koperasi Syariah Baitul Qiradh Karya Insan Sejahtera 43, dan Koperasi Syariah Baitul Qiradh Abu Indrapuri telah sesuai dengan PSAK 105, sedangkan Koperasi Syariah Mitra Niaga dan Koperasi Simpan Pinjam Dana Mandiri Syariah belum sepenuhnya sesuai, ketidaksesuaian pada Koperasi Syariah Mitra Niaga terdapat pada nisbah bagi hasil dimana mereka masih menetapkan margin atas bagi hasil usaha mudharabah. Ketidaksesuaian pada Koperasi Simpan Pinjam Dana Mandiri Syariah adalah tidak mengakui penurunan nilai investasi sebaga kerugian dan menetakan margin atas bagi hasil usaha mudharabah

2. Perlakuan akuntansi atas pengungkapan pada Koperasi Syariah Baitul Qiradh Al-Istiqamah, Koperasi Syariah Baitul Qiradh Karya Insan Sejahtera 43, Koperasi Syariah Mitra Niaga dan Koperasi Simpan Pinjam Dana Mandiri Syariah belum sepenuhnya sesuai.

3. Perlakuan akuntansi atas penyajian pada Koperasi Syariah Baitul Qiradh Al-Istiqamah, Koperasi Syariah Baitul Qiradh Karya Insan Sejahtera 43, Koperasi Syariah Mitra Niaga dan Koperasi Simpan Pinjam Dana Mandiri Syariah telah sesuai dengan PSAK 105 yaitu menyajikan pembiayaan mudharabah pada laporan keuangan sebesar nilai yang tercatat.

4. Perlakuan akuntansi atas pengungkapan pada Koperasi Syariah Baitul Qiradh Al-Istiqamah, Koperasi Syariah Baitul Qiradh Karya Insan Sejahtera 43, Koperasi Syariah Mitra Niaga dan
Koperasi Simpan Pinjam Dana Mandiri Syariah belum sepenuhnya sesuai.

\section{Keterbatasan}

Penelitian ini memiliki keterbatasanketerbatasan, yaitu:

1. Penelitian ini masih terbatas penerapan PSAK 105 pada pengakuan, pengukuran, penyajian, dan pengungkapan pembiayaan mudharabah, dalam penelitian tidak membahas prosedur pembiayaan mudharabah secara keseluruhan.

2. Data dan informasi yang didapatkan peneliti pada beberapa koperasi masih sedikit sehingga mempersulit dalam menganalisa kesesuaian penerapan PSAK 105.

3. Masih kurangnya pengetahuan SDM koperasi syariah tentang PSAK Syariah, terutama PSAK 105 yang mengatur tentang akuntansi mudharabah.

\section{Saran}

Berdasarkan kesimpulan dan keterbatasan penelitian diatas, ada beberapa saran untuk peneliti selanjutnya dan para praktisi, yaitu:

1. Pada peneliti selanjutnya diharapkan dapat menambah ruang lingkup penelitian, tidak terbatas pada pengakuan, pengukuran, penyajian, dan pengungkapan tetapi mendalam pada prosedur transaksi mudharabah.

2. Koperasi syariah di Aceh besar diharapkan dapat menerapkan sistem syariah secara keseluruhan terhadap perlakuan akuntansinya.

3. Dinas koperasi dan UMKM Aceh Besar diharapkan dapat memberikan pelatihan tentang PSAK syariah dan memberikan kebijakan baru untuk menerapkan sistem akuntansi yang syariah kepada koperasi-koperasi syariah di Aceh Besar

\section{Daftar Pustaka}

Antonio, M. S. (2007). Bank Syariah: Dari Teori ke Praktik. Jakarta: Gema Insani.

Darsono, Sakti, A., Astiyah, S., Darwis, A., \& Suryanti, E. T. (2017). Dinamika Produk Dan Akad Keuangan Syariah Di Indonesia. Depok: Rajawali Pers.

Effendi, S. (2014). Implementasi Akuntansi Syariah Pada Pembiayaan Mudharabah Berdasarkan PSAK No. 105 Pada KJKS BMT Al-Hayyu Kota Batam . Jurnal Measurement. 
Ikhsan, A., \& Haridhi, M. (2017). Penerapan Standar Akuntansi Keuangan Syariah Pada Koperasi Jasa Keuangan Syariah (Studi Pada Baitul Qiradh Di Kota Banda Aceh). Jurnal Ilmiah Mahasiswa Ekonomi Akuntansi (JIMEKA).

Indonesia, I. A. (2017). Standar Akuntansi Keuangan Syariah. Jakarta: Grha Akuntan.

Indonesia, K. K. (2018). Nomor Induk Koperasi. Retrieved from Data Koperasi: nik.dekop.go.id

Irlanda, M. O., \& Djazari. (2017). Analisis Penerapan PSAK No. 105 Atas Pembiayaan Mudharabah Pada BPRS Bangun Drajat Warga dan BPRS Madina Mandiri Sejahtera Yogyakarta. Jurnal Profita.

Keuangan, O. J. (2018). Statistik LKM. Retrieved from www.ojk.go.id

Moleong. (2012). Metode Penelitian Kualitatif. Edisi Revisi. Bandung: PT Remaja Rosdakarya

Nurhayati, S., \& Wasilah. (2015). Akuntansi Syariah Di Indonesia. Jakarta : Salemba Empat.

Permata, F. E., \& Wartoyo. (2017). Analisis Penerapan PSAK no. 105 Pada Tabungan Berjangka Mudharabah dan Pembiayaan Mudharabah. Jurnal Ekonomi Dan Perbankan Syariah.

Pertiwi, P. A., \& Sapari. (2017). Penerapan Sistem Bagi Hasil Dan Perlakuan Akuntansi Pembiayaan Mudharabah. Jurnal Ilmu Dan Riset Akuntansi.

Purwoko, S., \& Setiawan, N. (2017). Analisis Penerapan Akuntansi Pembiayaan Mudharabah Berdasarkan PSAK 105. Jurnal Profita.

Sakib, N. (2015). Conformity Level of AAOIFI Accounting Standards by Six Islamic Banks of Bangladesh . European Journal of Bussiness and Management.

Sekaran, U., \& Bougie, R. (2013). Research Method For Business: A Skill Building Approach, Sixth Edition. Jakarta: Salemba Empat.

Sofia, H. (2018, April 16). Kemenkop Ingatkan Pelaku UMKM Tertib Administrasi Pembukuan.

Diambil kembali dari Antara News : http://m.antaranews.com.

Sugiyono. (2013). Metode Penelitian Kuantitatif, Kualitatif, dan R\&D. Bandung: Alfabeta.

Suyoto, \& Endratno, H. (2015). Peran Baitul Maal wat Tamwil Dalam Meningkatkan Kinerja Usaha Rumah Tangga di Purwokerto. Sainteks.
Syahdeini, S. R. (1999). Perbankan Islam dan Kedudukannya Dalam Tata Hukum Perbankan Indonesia. Jakarta: Pustaka Grafiti.

UKM, H. K. (2016, Oktober 28). Kinerja Koperasi Syariah Di Indonesia Sangat Baik. Retrieved from Kementrian Koperasi dan UKM: Http://www.depkop.go.id

Wiroso. (2011). Akuntansi Transaksi Syariah. Edisi Revisi. Jakarta: Ikatan Akuntan Indonesia.

Yaya, R., Martawireja, A. E., \& Abdurahim, A. (2016). Akuntansi Perbankan Syariah: Teori dan Praktik Kontemporer. Jakarta: Salemba Empat.

Yusran, A. H., \& Leila, H. (2017). Penelitian Bisnis Pendekatan Kuantitatif. Depok: Kencana. 